\title{
Kadar Protein S-100 Serum Penderita Fraktur Oromaksilofasial yang Disertai Cedera Kepala Ringan
}

\author{
Hayana Miguna, ${ }^{1}$ H. M. Z. Arifin ${ }^{2}$ \\ ${ }^{1}$ Departemen Bedah Mulut Fakultas Kedokteran Gigi Universitas Padjadjaran-Rumah Sakit Dr. Hasan \\ Sadikin Bandung \\ ${ }^{2}$ Departemen Bedah Saraf Fakultas Kedokteran Universitas Padjadjaran-Rumah Sakit Dr. Hasan \\ Sadikin Bandung
}

\begin{abstract}
Abstrak
Penderita fraktur oromaksilofasial sering disertai dengan cedera kepala karena letak dan strukturnya yang berdekatan. Penilaian kemungkinan untuk lesi intrakranial setelah cedera kepala ringan merupakan tantangan utama dalam mendiagnosisnya. Salah satu metode yang dapat digunakan yaitu dengan menggunakan biomarker (petanda biokimia) protein S-100 serum yang merupakan protein neuron-spesifik. Tujuan penelitian adalah untuk menilai peningkatan kadar protein S-100 serum dan melihat perbedaannya berdasarkan lokasi fraktur oromaksilofasial pada cedera kepala ringan. Penelitian ini menggunakan metode studi kasus kontrol yang dilakukan di RS Dr. Hasan Sadikin Bandung pada bulan November 2010-Januari 2011. Sampel berjumlah 76 orang yang terdiri atas 38 penderita dewasa fraktur oromaksilofasial disertai dengan cedera kepala ringan dan 38 orang dewasa sehat sebagai kontrol. Hasil penelitian menunjukkan bahwa pada penderita fraktur oromaksilofasial dengan cedera kepala ringan diperoleh kadar protein S-100 serum rata-rata meningkat sebanyak dua kali lipat, yang secara statistik signifikan dengan $\mathrm{t}$ hitung $=2,26$ atau nilai $\mathrm{p}=0,0135$. Bila kelompok penderita yang satu dibandingkan dengan kelompok penderita lainnya, maka didapatkan hasil yang tidak signifikan secara statistik atau dapat dikatakan mempunyai kadar protein S-100 serum yang sama. Simpulan, pada penderita dewasa fraktur oromaksilofasial disertai cedera kepala ringan terdapat peningkatan kadar protein S-100 serum dan tidak terdapat perbedaan kadar protein S-100 serum berdasarkan lokasi fraktur oromaksilofasial. [MKB. 2012;44(4):233-39].
\end{abstract}

Kata kunci: Cedera kepala ringan, fraktur oromaksilofasial, protein S-100 serum

\section{Serum Levels of S-100 Protein in Oromaxillofacial Fracture Patients with Mild Head Injury}

\begin{abstract}
Oromaxillofacial fracture is often accompanied by head injury due to its adjacent location and structure. Risk estimation for clinically relevant intracranial lesions after minor head injury remains a major diagnostic challenge. One possible method to evaluate the possibility of intracranial lesion is by using biomarkers (biochemical marker) protein S-100. Protein S-100 is a neuron-specific protein. The aim of present study was to assess the elevated levels of S-100 protein serum and to investigate whether there was any difference in the S-100 protein serum concentrations depending on the location of the oromaxillofacial fractures in mild head injury. This study was performed using analytic observational method with case control research design conducted at Dr. Hasan Sadikin General Hospital Bandung between November 2010 and January 2011. There were 76 samples, comprised of 38 adult patients with oromaxillofacial and mild head injury and 38 healthy adults as a control group. The result showed that there was an increase level of S-100 protein serum concentrations in patients having oral and maxillofacial fractures with mild head injury. The concentration increased on average twice as much, which was statistically significant at $t$ test $=2.26$ with $p$-value $=0.0135$. If one group of patients was compared with other patient groups, however, the results were not statistically significant, or it can be stated to have the same level of S-100 protein serum concentrations. In conclusion, oral and maxillofacial fractures in adult patients with mild head injury have elevated levels of S-100 protein serum concentrations and there is no difference in S-100 protein serum concentrations based on the location of oromaxillofacial fractures in mild head injury. [MKB. 2012;44(4):233-39].
\end{abstract}

Key words: Mild head injury, oromaxillofacial fracture, S-100 protein serum

Korespondensi: Hayana Miguna, drg., Sp.BM, Departemen Bedah Mulut Fakultas Kedokteran Gigi Universitas PadjadjaranRumah Sakit Dr. Hasan Sadikin, jalan Pasteur 38 Bandung, e-mail hayana_miguna@yahoo.com 


\section{Pendahuluan}

Keparahan fraktur pada daerah wajah sangat bervariasi. Fraktur wajah dapat disertai dengan berbagai komplikasi yang mayoritas mengenai kepala. ${ }^{1,2}$ Struktur maksilofasial dapat berfungsi sebagai peredam gaya, tetapi selain itu struktur oromaksilofasial secara nyata dapat meneruskan gaya trauma secara langsung ke neurokranium, dan mampu mengakibatkan trauma yang lebih berat pada otak. ${ }^{3,4}$ Pada penelitian Davidoff dkk. ${ }^{5}$ diungkapkan bahwa 55\% penderita fraktur tulang muka memiliki cedera penyerta trauma kepala. Nakhgevany dkk. ${ }^{6}$ menyatakan $68 \%$ kasus trauma wajah memiliki cedera kepala penyerta.

Cedera kepala menjadi salah satu masalah besar ilmu kesehatan modern saat ini. Insidensi tertinggi cedera kepala terjadi pada pria usia 1524 tahun. Cedera kepala menjadi penyebab utama kematian dewasa muda yang berusia di bawah 45 tahun. Sekitar $70 \%$ penderita trauma mengalami cedera kepala berat yang mematikan dan sisanya yang bertahan hidup mengalami kecacatan. ${ }^{7}$

Kemungkinan lesi intrakranial yang relevan secara klinis setelah cedera kepala ringan dapat dinilai dengan Glasgow coma scale (GCS). Nilai GCS 14-15 tetap merupakan tantangan utama dalam mendiagnosisnya. ${ }^{8-10}$

Salah satu metode yang dapat dipergunakan untuk deteksi gangguan fungsional dan struktural yaitu biomarker (petanda biokimia) cedera kepala. Petanda biokimia berguna di dalam menentukan diagnosis cedera kepala secara cepat sebelum tanda dan gejala berdasarkan neuroradiographic muncul, dan dapat memperkirakan besar kecilnya trauma. 9,10

Beberapa petanda biokimia dapat digunakan pada kasus cedera kepala antara lain creatine kinase (CK), lactate dehydrogenase (LDH), myelin basic protein (MBP), neuron-specific enolase (NSE), glial fibrillary acidic protein (GFAP), serta protein S-100. Spesifisitas NSE terhadap jaringan otak menunjukkan hasil yang tinggi. Berdasarkan penelitian yang dilakukan oleh Ruslin ${ }^{11}$ dinyatakan bahwa pengukuran kadar NSE dapat digunakan sebagai salah satu petanda cedera kepala, tetapi penelitian berkaitan dengan peningkatan NSE serum terhadap GCS penderita pada cedera kepala berat menunjukkan hasil bertentangan. Pada cedera kepala ringan, NSE gagal memisahkan penderita dari kontrol. Karenanya, NSE secara predominan digunakan sebagai tumor marker. Selain itu, NSE juga dilepaskan ke dalam darah disebabkan hemolisis yang dapat merupakan sumber utama kekeliruan. ${ }^{11}$

Protein S-100 adalah protein neuron-spesifik yang disintesis dalam sel astroglia seluruh bagian dari sistem saraf pusat (SSP). Protein ini kadarnya sangat rendah dalam serum pada keadaan normal, tetapi akan meningkat setelah strok, perdarahan subaraknoid, cedera kepala, dan operasi bypass. Karena kerusakan jaringan glial yang diikuti dengan gangguan blood brain barrier (BBB), maka protein ini dilepaskan ke dalam serum, oleh karena itu konsentrasi protein S-100 serum dapat mengindikasikan luasnya kerusakan jaringan otak. ${ }^{10,11}$

Fraktur oromaksilofasial umumnya disertai dengan cedera kepala. Konsentrasi S-100 serum yang meningkat dapat mengindikasikan luasnya kerusakan jaringan otak. Hubungan antara lokasi fraktur oromaksilofasial dan luasnya kerusakan SSP masih bersifat kontroversi. Keenan dkk. ${ }^{12}$ menyimpulkan risiko cedera otak karena trauma meningkat pada penderita fraktur tulang wajah. Lee dkk. ${ }^{3}$ menunjukkan bahwa risiko tertinggi cedera kepala didapatkan pada fraktur maksila. Pada penelitian retrospektif yang dilakukan oleh Rajendra dkk. ${ }^{13}$ didapatkan hilangnya kesadaran penderita fraktur fasial terbanyak pada fraktur mandibula, diikuti zigoma dan terakhir maksila. Keadaan ini bertolak belakang dengan hasil yang didapatkan Keenan dkk. ${ }^{12}$

Penelitian ini bertujuan menilai peningkatan kadar S-100 serum pada penderita dewasa fraktur oromaksilofasial disertai cedera kepala ringan dan menilai perbedaan kadar protein S-100 serum berdasarkan lokasi fraktur oromaksilofasial pada cedera kepala ringan.

\section{Metode}

Penelitian ini merupakan studi observasional analitik dengan rancangan kasus kontrol. Analisis data disesuaikan dengan tujuan penelitian dan hipotesis yang dikemukakan. Untuk membuktikan kenaikan kadar S-100 serum pada kelompok penderita dewasa dan kelompok dewasa sehat mempergunakan uji perbandingan dua rata-rata, dengan uji $t$ student.

Untuk menilai perbedaan kadar S-100 serum pada penderita cedera kepala ringan berdasarkan lokasi fraktur dipergunakan uji perbandingan rata-rata dengan analysis of variance (ANOVA).

Subjek pada penelitian ini adalah penderita dewasa dengan fraktur oromaksilofasial disertai cedera kepala ringan yang datang melalui Unit Gawat Darurat (UGD) ataupun dirawat di Departemen Bedah Saraf atau Bedah Mulut dan Maksilofasial Rumah Sakit Umum Pusat (RSUP) Dr. Hasan Sadikin Bandung selama periode November 2010 sampai Januari 2011, dengan kriteria inklusi nilai GCS $14-15$ dalam fase 24 jam pertama, usia 14-65 tahun, baik pria maupun wanita. Kriteria eksklusi yaitu di bawah pengaruh 
Hayana Miguna: Kadar Protein S-100 Serum Penderita Fraktur Oromaksilofasial yang Disertai Cedera Kepala Ringan

Tabel 1 Karakteristik Subjek pada Kedua Kelompok Penelitian

\begin{tabular}{lcc}
\hline Variabel & \multicolumn{2}{c}{ Kelompok } \\
\cline { 2 - 3 } & $\begin{array}{c}\text { Kasus } \\
(\mathbf{n = 3 8 )}\end{array}$ & $\begin{array}{c}\text { Kontrol } \\
(\mathbf{n = 3 8 )}\end{array}$ \\
\hline Usia (tahun) & & \\
Rata-rata & 29,16 & \\
Simpangan baku & 14,18 & \\
Rentang & $14-63$ & 24,03 \\
Jenis kelamin & & 1,92 \\
Laki-laki & 30 & $22-34$ \\
Perempuan & 8 & \\
Nilai GCS & $5(13 \%)$ & 2 \\
14 & $33(87 \%)$ & \\
15 & 7,03 & \\
Waktu paruh (jam) & 5,25 & \\
Rata-rata & $2-24$ & \\
Simpangan baku & & \\
Rentang &
\end{tabular}

alkohol, disertai cedera organ lain seperti trauma toraks, abdomen, pelvis, dan ekstremitas, serta terdapat melanoma berdasarkan anamnesis dan pemeriksaan fisis.

Sebagai kelompok kontrol yaitu pria dan wanita yang sehat jasmani dan rohani berdasarkan pemeriksaan fisis dan laboratorium pada saat melakukan medical check-up di RS Dr. Hasan Sadikin Bandung, berusia 14-65 tahun. Kriteria eksklusi yaitu penderita penyakit jantung, strok, serta melanoma berdasarkan anamnesis dan juga pemeriksaan fisis.

Pemeriksaan kadar S-100 serum dilakukan dengan cara mengambil $3 \mathrm{mLdarah}$ dari vena kubiti menggunakan tabung khusus bertekanan negatif (vacutainer) dengan jarum sekali pakai. Dalam penelitian ini untuk menentukan kadar S-100 serum dipergunakan electrochemiluminescence immune assay (ECLIA).

\section{Hasil}

Subjek penelitian terdiri atas 38 penderita dewasa fraktur oromaksilofasial yang disertai dengan cedera kepala ringan dan 38 orang kelompok sehat/kontrol.

Usia rata-rata pada kelompok kasus 29 tahun, simpangan baku 14,18, dan rentang usia berkisar antara 14 tahun sampai 63 tahun (Tabel 1). Uji perbedaan berdasarkan beberapa kelompok usia (Tabel 2) menunjukkan hasil yang tidak signifikan secara statistik ( $\mathrm{F}$ hitung $=0,83$ dan nilai $\mathrm{p}=0,54)$, sehingga dapat disimpulkan penderita usia tua atau muda memiliki kadar S-100 serum rata-rata yang dianggap sama.

Pada kelompok kasus penderita laki-laki lebih banyak daripada perempuan. Pada kelompok kasus dilakukan uji t (t hitung $=2,10$ dan nilai $\mathrm{p}=0,02$ ), yang menunjukkan hasil yang signifikan secara statistik, sehingga dapat disimpulkan kadar S-100 serum pada laki-laki lebih rendah daripada perempuan.

Pada kelompok kasus, didapatkan penderita dengan nilai GCS 15 sebanyak 33 orang dan nilai GCS 14 sebanyak 5 orang (Tabel 1). Uji t (t hitung $=0,41$ dan nilai $\mathrm{p}=0,3415$ ) menunjukkan hasil tidak signifikan secara statistik, sehingga dapat dikatakan penderita dengan nilai GCS 14 dan GCS 15 memiliki kadar protein S-100 serum

Tabel 2 Uji Berpasangan Kelompok Usia

\begin{tabular}{cccccccc}
\hline Usia & Kadar Protein & $\mathbf{5 0 - 5 9}$ & $\mathbf{1 0}-\mathbf{1 9}$ & $\mathbf{4 0 - 4 9}$ & $\mathbf{2 0}-\mathbf{2 9}$ & $\mathbf{6 0}-\mathbf{6 9}$ & $\mathbf{3 0}-\mathbf{3 9}$ \\
\cline { 3 - 8 } & $\mathbf{0 , 0 9}$ & $\mathbf{0 , 1 0}$ & $\mathbf{0 , 1 1}$ & $\mathbf{0 , 1 2}$ & $\mathbf{0 , 2 2}$ & $\mathbf{0 , 3 6}$ \\
\hline $50-59$ & 0,09 & & & & & & \\
$10-19$ & 0,10 & 0,8266 & & & & & \\
$40-49$ & 0,11 & 0,8301 & 0,8591 & & & & \\
$20-29$ & 0,12 & 0,7810 & 0,6597 & 0,9209 & & & \\
$60-69$ & 0,22 & 0,5306 & 0,1111 & 0,5942 & 0,3999 & & \\
$30-39$ & 0,36 & 0,5771 & 0,1497 & 0,6048 & 0,2567 & 0,7124 & \\
\hline
\end{tabular}


Hayana Miguna: Kadar Protein S-100 Serum Penderita Fraktur Oromaksilofasial yang Disertai Cedera Kepala Ringan

Tabel 3 Uji Berpasangan Waktu Paruh

\begin{tabular}{ccccccc}
\hline Jam & Kadar Protein & $\mathbf{9 - 1 2}$ & $\mathbf{1 3 - 1 6}$ & $\mathbf{2 1 - 2 4}$ & $\mathbf{5 - 8}$ & $\mathbf{0 - 4}$ \\
\cline { 3 - 7 } & $\mathbf{0 0 5 0 0 0 0}$ & $\mathbf{0 , 0 7 0 0 0 0}$ & $\mathbf{0 , 0 8 3 5 0 0}$ & $\mathbf{0 , 1 1 8 7 0 6}$ & $\mathbf{0 , 2 8 8 3 5 7}$ \\
\hline $9-12$ & 0,050000 & & & & & \\
$13-16$ & 0,070000 & 0,3631 & & & & \\
$21-24$ & 0,083500 & 0,2070 & 0,1855 & & & \\
$5-8$ & 0,118706 & 0,4032 & 0,5508 & 0,6656 & & \\
$0-4$ & 0,288357 & 0,5117 & 0,5472 & 0,5719 & 0,1718 & \\
\hline
\end{tabular}

Tabel 4 Kadar Protein S-100 Serum Rata-rata pada Kelompok Kasus dan Kelompok Kontrol

\begin{tabular}{ccc}
\hline & \multicolumn{2}{c}{ Kelompok } \\
\cline { 2 - 3 } & $\begin{array}{c}\text { Kasus }(\boldsymbol{\mu g} / \mathrm{L}) \\
(\mathbf{n}=\mathbf{3 8})\end{array}$ & $\begin{array}{c}\text { Kontrol } \\
(\boldsymbol{\mu g} / \mathbf{L}) \\
(\mathbf{n = 3 8})\end{array}$ \\
\hline $\begin{array}{c}\text { Rata-rata } \\
\text { Simpangan } \\
\text { baku }\end{array}$ & 0,171 & 0,057 \\
\hline
\end{tabular}

yang dianggap sama.

Waktu paruh rata-rata kelompok kasus 7 jam dengan simpangan baku 5,25 dan rentang waktu paruh berkisar antara 2 sampai 24 jam. Hasil uji perbedaan berdasarkan beberapa kelompok waktu paruh (Tabel 3) penderita menunjukkan hasil pengujian yang tidak signifikan secara statistik ( $F$ hitung $=0,74$ ), sehingga dapat disimpulkan kadar S-100 serum rata-rata berdasarkan waktu paruh tidak memiliki perbedaan secara statistik.

Pada kelompok kasus, kadar S-100 serum ratarata $0,171 \mu \mathrm{g} / \mathrm{L}$ dengan simpangan baku 0,3114 , sedangkan pada kelompok kontrol sebesar 0,057 $\mu \mathrm{g} / \mathrm{L}$ dengan simpangan baku 0,0190 (Tabel 4).

Hasil pengujian menunjukkan $t$ hitung $=2,26$ atau $p=0,0135$ yang signifikan secara statistik. Hal ini memperlihatkan bahwa pada penderita fraktur oromaksilofasial dengan cedera kepala ringan diperoleh kadar protein S-100 serum ratarata meningkat sebanyak dua kali lipat. Jumlah kasus terbanyak pada kelompok II (fraktur 1/3 tengah wajah) sebanyak 10 kasus. Pada kelompok kasus V (fraktur $1 / 3$ atas dan $1 / 3$ bawah wajah) tidak ditemukan penderita (Tabel 5).

Uji ANOVA berdasarkan data dalam Tabel 5 diperoleh $F$ hitung $=3,33$ atau nilai $p=0,0061$ yang signifikan secara statistik, artinya jika penderita fraktur oromaksilofasial dengan cedera kepala ringan dikelompokkan berdasarkan lokasi fraktur maka terdapat perbedaan kadar protein S-100 serum rata-rata dibandingkan dengan kontrol.

Uji setelah ANOVA yaitu uji berpasangan dengan uji t terlihat pada Tabel 6. Jika kelompok kasus yang satu dibandingkan dengan kelompok kasus lainnya maka tidak terdapat perbedaan kadar protein S-100 serum yang signifikan secara statistik, sehingga dapat disimpulkan bahwa tidak ada perbedaan peningkatan kadar protein S-100 serum rata-rata berdasarkan lokasi terjadinya fraktur.

Tabel 5 Kadar Protein S-100 Serum Rata-rata berdasarkan Lokasi Fraktur dan Kelompok Kontrol

\begin{tabular}{cccc}
\hline Kelompok & n & Simpangan Baku & $\begin{array}{c}\text { Protein S-100 }(\boldsymbol{\mu g} / \mathbf{L}) \\
\text { Rata-rata }\end{array}$ \\
\hline I & 3 & 0,0680 & 0,102 \\
II & 10 & 0,1463 & 0,143 \\
III & 4 & 0,0621 & 0,095 \\
IV & 9 & 0,0638 & 0,099 \\
$*$ V & 0 & 0 & 0 \\
VI & 9 & 0,0751 & 0,127 \\
VII & 3 & 0,2495 & 0,207 \\
Kontrol & 38 & 0,0190 & 0,057 \\
\hline
\end{tabular}

Keterangan: $\mathrm{I}=$ fraktur $1 / 3$ atas wajah, $\mathrm{II}=$ fraktur $1 / 3$ tengah wajah, III= fraktur $1 / 3$ bawah wajah,IV= fraktur $1 / 3$ atas $+1 / 3$ tengah wajah, $V=$ fraktur $1 / 3$ atas $+1 / 3$ bawah wajah, VI= fraktur $1 / 3$ tengah $+1 / 3$ bawah wajah, VII= fraktur $1 / 3$ atas, $1 / 3$ tengah, dan $1 / 3$ bawah wajah., *tidak didapatkan sampel 
Hayana Miguna: Kadar Protein S-100 Serum Penderita Fraktur Oromaksilofasial yang Disertai Cedera Kepala Ringan

Tabel 6 Uji Berpasangan

\begin{tabular}{|c|c|c|c|c|c|c|c|c|}
\hline \multirow[t]{2}{*}{ Kontrol } & \multirow[b]{2}{*}{ Mean } & \multicolumn{2}{|r|}{ III } & \multirow{2}{*}{$\begin{array}{c}\text { IV } \\
0,099\end{array}$} & \multirow{2}{*}{$\frac{I}{0,102}$} & \multirow{2}{*}{$\frac{\text { VI }}{0,127}$} & \multirow{2}{*}{$\frac{\text { II }}{0,143}$} & \multirow{2}{*}{$\frac{\text { VII }}{0,207}$} \\
\hline & & 0,057 & 0,095 & & & & & \\
\hline & 0,057 & & & & & & & \\
\hline III & 0,095 & 0,0059 & & & & & & \\
\hline IV & 0,099 & 0,0009 & 0,9227 & & & & & \\
\hline I & 0,102 & 0,0031 & 0,8876 & 0,9359 & & & & \\
\hline VI & 0,127 & 4.22E-06 & 0,4770 & 0,4067 & 0,6300 & & & \\
\hline II & 0,143 & 0,0007 & 0,5456 & 0,4146 & 0,6573 & 0,7689 & & \\
\hline VII & 0,207 & 0,0001 & 0,4147 & 0,2243 & 0,5219 & 0,3773 & 0,5785 & \\
\hline
\end{tabular}

\section{Pembahasan}

Letak geografis, status sosial ekonomi, kultur, dan pengaturankeselamatandijalan rayamemengaruhi penyebab dan insidensi trauma maksilofasial.,14

Penelitian yang dilakukan oleh Van Engelen $\mathrm{dkk} \cdot{ }^{15}$ ditemukan bahwa konsentrasi protein S-100 serum meningkat seiring dengan bertambahnya usia. Hasil tersebut berbeda dengan hasil yang didapatkan penelitian ini, bahwa setiap kelompok usia, tua atau muda, memiliki kadar protein S-100 serum yang dianggap sama.

Nygard dkk. ${ }^{16}$ menemukan bahwa pada pria ditemukan kadar protein S-100 serum yang lebih tinggi bila dibandingkan dengan wanita, bertolak belakang dengan hasil pada penelitian ini, yaitu kadar protein S-100 serum pada laki-laki lebih rendah daripada perempuan. Perbedaan hasil penelitian ini kemungkinan dapat disebabkan karena jumlah sampel yang lebih banyak pada penderita pria, yaitu 30 dari 38 subjek.

Abdesselam dkk. ${ }^{17}$ melakukan penelitian terhadap ras individu dan didapatkan hasil bahwa individu Afrika dan Asia memiliki kadar S-100 serum yang lebih tinggi dibandingkan dengan Caucasian. Pada penelitian ini, semua penderita adalah orang Asia, sehingga tidak dapat dilakukan penilaian perbedaan kadar serum berdasarkan ras individu.

Nilai GCS dapat tidak sesuai dengan perkiraan oleh karena perbedaan yang sangat kecil antara cedera kepala ringan dan cedera kepala sedang. Belakangan ini, penderita dengan nilai GCS 13 telah dipindahkan dari kategori ringan menjadi kategori sedang. Pada klasifikasi cedera kepala ringan terbaru ditetapkan nilai GCS 14-15.18,19 $\mathrm{Hal}$ ini sesuai dengan hasil yang didapatkan pada penelitian ini, yaitu penderita dengan nilai GCS 14 dan GCS 15 memiliki kadar protein S-100 serum yang dianggap sama. Hasil penelitian ini sesuai dengan kategori cedera kepala ringan meliputi nilai GCS 14 dan GCS 15.
Protein S-100 dimetabolisme di ginjal dan diekskresikan melalui urin dan memiliki waktu paruh biologis 2 jam. ${ }^{10}$ Pada cedera kepala ringan dengan waktu paruh 2 jam, kadar dalam serum umumnya akan kembali ke ambang batas dalam beberapa jam. ${ }^{20}$ Sampel darah yang dikumpulkan pada penelitian ini berkisar antara 2 jam sampai 24 jam setelah kejadian, dengan rata-rata sekitar 7 jam seperti yang terlihat pada Tabel 1. Hasil uji perbedaan berdasarkan beberapa kelompok waktu paruh menunjukkan hasil pengujian yang tidak signifikan secara statistik ( $\mathrm{F}$ hitung $=0,74$ ), sehingga dapat disimpulkan kadar protein S-100 serum rata-rata berdasarkan waktu paruh tidak memiliki perbedaan secara statistik.

Protein S-100 merupakan protein neuronspesifik yang disintesis dalam sel astroglia di seluruh bagian sistem saraf pusat (SSP). Protein ini kadarnya sangat rendah dalam serum pada keadaan normal, akan tetapi meningkat setelah terjadi cedera kepala. ${ }^{10}$ Protein S-100 mencapai aliran darah dengan mudah karena kerusakan jaringan glia yang diikuti dengan gangguan fungsi blood brain barrier. Oleh karena itu, nilai protein S-100 serum setelah cedera kepala dapat mengindikasikan luas kerusakan jaringan otak. ${ }^{15}$ Teori ini sesuai dengan hasil yang diperlihatkan pada Tabel 4, yaitu bahwa kadar protein S-100 serum pada kelompok penderita meningkat dua kali lipat dibandingkan dengan kelompok sehat.

Fraktur nasal paling sering terjadi dan biasanya fraktur pada maksila disertai fraktur tulang wajah lainnya terutama tulang nasal. ${ }^{1}$ Pada penelitian ini, tidak ditemukan kasus kombinasi fraktur sepertiga atas dan sepertiga bawah wajah (Tabel 5), sehingga dapat dikatakan suatu daya benturan yang menyebabkan fraktur pada sepertiga atas dan sepertiga bawah wajah merupakan kasus yang sulit terjadi tanpa mengikutsertakan daerah sepertiga tengah wajah.

Beberapa penelitian yang telah dilakukan dengan beragam cara untuk mengetahui risiko terjadinya cedera otak dan fraktur maksilofasial 
menunjukkan hasil yang berlainan antara satu dan lainnya. ${ }^{3,12,13}$

Keenan dkk. ${ }^{12}$ menyimpulkan bahwa risiko cedera otak traumatika meningkat pada penderita fraktur tulang wajah. Lee $\mathrm{dkk} .^{3}$ menunjukkan bahwa risiko tertinggi cedera kepala didapatkan pada fraktur maksila. Pada penelitian retrospektif yang dilakukan oleh Rajendra dkk. ${ }^{13}$ didapatkan hilangnya kesadaran pada fraktur fasial, paling banyak ditemukan pada fraktur mandibula, diikuti zigoma, dan terakhir maksila. Perbedaan hasil ini dapat disebabkan karena struktur maksilofasial selain untuk melindungi neurokranium dapat pula meneruskan gaya trauma ke neurokranium, sehingga mengakibatkan trauma yang lebih berat pada otak. ${ }^{3,4}$ Hasil penelitian ini (Tabel 6), kadar protein S-100 serum belum menunjukkan perbedaan yang signifikan antara masing-masing kelompok penderita dewasa dengan cedera kepala ringan yang dibagi berdasarkan lokasi fraktur oromaksilofasial. Hasil ini tidak mendukung teori ataupun hasil penelitian lainnya. Hal ini dapat disebabkan karena setiap kelompok mempunyai jumlah sampel yang berbeda dan kecil. Hal ini merupakan salah satu keterbatasan penelitian.

Simpulan, terdapat peningkatan kadar protein S-100 serum sebanyak dua kali lipat pada penderita dewasa fraktur oromaksilofasial disertai cedera kepala ringan dan tidak terdapat perbedaan kadar protein S-100 serum berdasarkan lokasi fraktur oromaksilofasial pada cedera kepala ringan.

\section{Daftar Pustaka}

1. Booth PW, Schendel SA, Hausamen JE. Maxillofacial surgery. Edisi ke-2. St. Louis: Churchill Livingstone; 2007.

2. Fonseca RJ. Oral and maxillofacial surgery. Edisi ke-3. New York: Thieme Stuttgart; 1997.

3. Lee KF, Wagner LK, Lee YE, Suh JH, Lee Sr. The impact-absorbing effects of facial fractures in closed-head injuries. An analysis of 210 patients. J Neurosurg. 1987;66(4):542-7.

4. Ruslin M, Arifin MZ. Hubungan fraktur maksilofasial dengan perdarahan intrakranial, fraktur basis kranii serta tingkat kesadaran pada penderita cedera kepala. MKB. 2007;39(3):115-9.

5. Davidoff $G$, Jakubowski M, Thomas D, Alpert M. The spectrum of closed-head injuries in facial trauma victims: incidence and impact. Ann Emerg Med. 1988;17(1):69.

6. Nakhgevany KB, LiBassi M, Esposito B. Facial trauma in motor vehicle accidents: etiological factors. Am J Emerg Med. 1994;12(2):160-3.

7. Vos PE, Battistin L, Birbamer G, Gerstenbrand F, Potapov A, Prevec T,dkk. EFNS guideline on mild traumatic brain injury: report of an EFNS task force. Eur J Neurol. 2002;9(3):207-19.

8. Poli-de-Figueiredo LF, Biberthaler P, Simao Filho C, Hauser C, Mutschler W, Jochum M. Measurement of S-100B for risk classification of victims sustaining minor head injury - first pilot study in Brazil. Clinics. 2006;61(1):416.

9. de Boussard CN, Lundin A, Karlstedt D, Edman G, Bartfai A, Borg J. S 100 and cognitive impairment aftermild traumatic brain injury. J Rehabil Med. 2005;37(1):537.

10. Hayes RL. Biochemical markers of brain injury: applications to combat casualty care. Presented at the RTO HFM symposium on Combat Casualty Care in Ground Based Tactical Situations: Trauma Technology and Emergency Medical Procedures. USA, 1618 August 2004.

11. Ruslin M. Korelasi antara kadar neuronspecific enolase serum penderita dewasa dengan lokasi fraktur oromaksilofasial pada cedera kepala ringan [tesis]. Bandung: Universitas Padjadjaran; 2009.

12. Keenan HT, Brundage SI, Thompson DC, Maier RV, Rivana FP. Does the face protect the brain? A case control study of traumatic brain injury and facial fractures. Arch Surg. 1999;134(1):14-7.

13. Rajendra PB, Mathew TP, Agrawal A, Sabharawal G. Characteristics of associated craniofacial trauma in patients with head injuries: An experience with 100 cases. J Emerg Trauma Shock. 2009;2(2):89-94.

14. Laskin DM, Best AM. Current trends in the treatment of maxillofacial injuries in the United States. J Oral Maxillofac Surg. 2000;58(2):207-15.

15. Van Engelen BG, Lamers KJ, Gabreels FJ, Wevers RA, van Geel WJ, Borm GF. Agerelated changes of neuron-specific enolase, $\mathrm{S}-100$ protein, and myelin basic protein concentrations in cerebrospinal fluid. Clin Chem. 1992;38(6):813-6.

16. Nygaard Q, Langbakk B, Romner B. Ageand sex-related changes of S-100 protein concentrations in cerebrospinal fluid and serum in patients with no previous history of neurological disorder. Clin Chem. 1997;43(3):541-3.

17. Ben Abdesselam O, Vally J, Adem C, Foglietti MJ, Beaudeux JL. Reference values 
Hayana Miguna: Kadar Protein S-100 Serum Penderita Fraktur Oromaksilofasial yang Disertai Cedera Kepala Ringan

for serum S-100B protein depend on the race of individuals. Clin Chem. 2003;49(5):8367.

18. Bellner J, Jensen SM, Lexell J, Romner B. Diagnostic criteria and the use of ICD10 codes to define and classify minor head injury. J Neurol Neurosurg Psychiatry. 2003;74(3):351-2.
19. Rimel RW, Giordani B, Barth JT, Boll TJ, Jane JA. Disability caused by minor head injury. Neurosurgery. 1981;9(3):221-8.

20. Raabe A, Seifert V. Fatal secondary increase in serum S-100B protein after severe head injury. Report of three cases. J Neurosurg. 1999;91(5):875-7. 